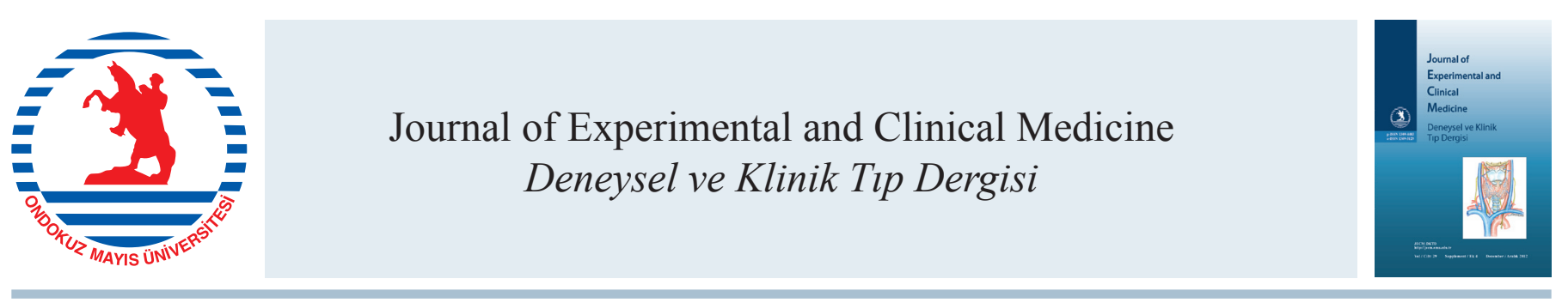

Derleme / Review

doi: $10.5835 /$ jecm.omu.29.s4.023

\title{
Tiroit hastalıklarında patolojik değerlendirme
}

Pathological examination in thyroidal diseases

İkser Akpolat*

Ondokuz Mayıs Üniversitesi, Tıp Fakültesi, Patoloji Anabilim Dalı, Samsun, Türkiye

\begin{tabular}{|c|c|}
\hline \multicolumn{2}{|c|}{ MAKALE BİLGÍLERİ } \\
\hline \multicolumn{2}{|c|}{ Makale geçmişi } \\
\hline Geliş tarihi & : 07 / 06 / 2012 \\
\hline Kabul tarihi & $: 08 / 10 / 2012$ \\
\hline
\end{tabular}

\section{* Yazışma Adresi:}

İlkser Akpolat

Ondokuz Mayıs Üniversitesi,

Tıp Fakültesi,

Patoloji Anabilim Dalı

Samsun 55139

e-posta: ilkserakpolat@yahoo.com

\author{
Anahtar Kelimeler: \\ Tiroit \\ Nodül \\ İnce iğne aspirasyon sitolojisi \\ Sitolojik değerlendirme \\ Patoloji \\ Multidisipliner yaklaşım
}

\section{ÖZET}

Tiroit bezinde s1k görülen problemler hipotiroidi, hipertiroidi, tiroidit, guatr ve tiroit nodülleridir. Hipo ve hipertiroidizmi olan hastaların çoğu biyokimyasal testlerle tanı alır. Patolojik inceleme nodüllerin değerlendirilmesinde kullanılır. Bu yazıda soliter nodüller hakkında kısa bir bilgi verilmiştir. Daha sonra ise ince iğne aspirasyon sitolojisi, biyopsi, sitolojik değerlendirme ve tiroit lezyonlarının patolojisinden bahsedilmiştir. Sonuç olarak tiroit hastalıklarında çok farklı patolojiler izlenebilir. Doğru yaklaşım için klinisyen, patolog, radyolog ve nükleer tıp uzmanını içeren multidisipliner yaklaşım gereklidir. J. Exp. Clin. Med., 2012; 29:S337-S348

\begin{abstract}
Common problems of thyroid gland are hypothyroidism, hyperthyroidism, thyroiditis, goitre, and thyroid nodules. Patients having hypothyroidism or hyperthyroidism are mostly diagnosed by biochemical tests. Pathological examination is used in the evaluation of nodules. This paper gives a short information about solitary nodules. Thereafter, it mentions about fine needle aspiration cytology, biopsy, cytological evaluation and pathology of thyroidal lesions. In conclusion, many types of pathological lesions can be seen in thyroid diseases. Multidisciplinary approach including clinician, pathologist, radiologist and nuclear medicine specialist is required for appropriate approach.

J. Exp. Clin. Med., 2012; 29: S337-S348
\end{abstract}

\section{Keywords:}

Thyroid

Nodule

Fine needle aspiration cytology

Cytological evaluation

Pathology

Multidisciplinary approach

\section{Giriş}

Tiroit ile ilgili en sık karşılaşılan problemler; hipotiroidizm, hipertiroidizm, tiroidit, guatr ve tiroit nodülleridir. Hipo ve hipertiroidizmi olan hastaların çoğu biyokimyasal testlerle tanınır ve tedavi edilirler. Patolojik inceleme nodüllerin değerlendirilmesinde uygulanır (Boerner ve Asa, 2010). Bu yazıda önce soliter nodüller hakkında kısa bir bilgi verilecek, daha sonra ise ince iğne aspirasyon sitolojisi (İIAS), biyopsi, sitolojik değerlendirme ve tiroit lezyonlarının patolojisinden bahsedilecektir (Baloch ve LiVolsi, 2004; DeLellis ve Williams, 2004; Boerner ve Asa, 2010; Maitra, 2010; Burlingame ve ark., 2011; Rosai ve Tallini, 2011).

\section{Soliter nodüllerin değerlendirilmesi}

Cerrah ve patoloğun en sık karşılaştığ de tek nodül olan hastanın değerlendirilmesidir (Rosai ve Tallini, 2011). Tiroit nodülleri; nodüler guatr, tiroidit ve soliter neoplaziye bağlı olarak gelişebilir. Tiroit nodülleri toplumda sıktır. Populasyonun yaklaşık \% 20'sinde palpabl, \% 70'inde ultrasonografi ile saptanan nodül bulunur. Nodüller kadınlarda daha sıktır ve çoğunlukla birden fazladır (Boerner ve Asa, 2010). Soliter nodül normal tiroit dokusundan ayrı palpe edilebilen tek şişliktir. Neoplastik olma olasılığı çok sayıda nodüle göre daha fazladır. Guatr için endemik bölgelerde daha sık görülür. ABD'de erişkinlerde hesaplanan insidans \% 1-10 
arasındadır. Kadınlarda dört kat daha fazladır. Bu nodüllerin de çoğu basit kist, dominant nodül, tiroidit odağ1 gibi lokalize neoplastik olmayan olaylardır. Benign neoplaziler malign olanlara göre yaklaşık 10 kat daha fazladır. Soliter nodüllerin yaklaşık \% 1'i maligndir. Malignlerin çoğu yavaş seyirlidir (Maitra, 2010). Bu nedenle cerrahi yapılacak hastaları seçerken karsinomların çoğunu içeren grubu oluşturmak temel amaçtır. Bu seçimi yaparken göz önünde bulundurulan bir çok faktör vardır (yaş, cinsiyet, nodül sayısı, ultrasonografi vs.). Cerrahi öncesinde deneyimli kişiler tarafindan yapılan ve değerlendirilen iğne biyopsisi bu nodüllerde malignitenin değerlendirilmesinde en iyi bilgiyi verir (Rosai ve Tallini, 2011). Tarihsel olarak klinik olarak şüpheli nodüllerin değerlendirilmesi için biyopsi lobektomi ya da hemitiroidektomi gibi çok sayıda cerrahi yapılması gerekiyordu. Ancak daha sonra nodüllerin değerlendirilmesinde ince iğne aspirasyonu sitolojisi (İ̇AS) önemli rol almıştır (Boerner ve Asa, 2010).

Tiroit doku yapısının korunması nedeni ile eskiden insizyonel biyopsi, yakın dönemlerde de iğne kor biyopsilerini tercih eden patologlar vardır. Ancak histolojik örneklemenin bazı dezavantajları İİS'nin daha çok önerilmesine neden olmaktadır (Boerner ve Asa, 2010). Kor biyopsiler dünyada geniş kabul görmemektedir (Rosai ve Tallini, 2011).

İnsizyonel biyopsi cerrahi girişimdir ve pahalıdır. Anatomik yapıların bozulmasına yol açarak daha sonra yapılacak cerrahileri zorlaştırır. İğne biyopsileri ayaktan uygulanabilir, anatomik yapılara daha az zarar verir. Ancak İİAS'ye göre başta kanama ve hematom açısından olmak üzere daha fazla risklidir. İnsizyonel ve kor biyopsi lezyonun yapısını bozabilir, skar ve hatta infarkta neden olur. İIAS' de de bu durum olabilir ama ince iğne kullanılması ile lezyonel hasar görülme sıklığı ve şiddeti azalır. Folliküler lezyon tanısının söz konusu olduğu durumlarda kesin tanı için cerrahi materyalde kapsülün tamamının incelenmesi gerekir. Biyopsi bu işlemin doğru yapılmasını engelleyebilir.

Yapılan çalışmalarda İIAS ve kor biyopsiler arasında tanısal açıdan kesin bir üstünlük gösterilememiştir. İmmünhistokimya (IHC), genetik çalışmalar ek yöntemler biyopsi materyalinde uygulandığı gibi İİAS'de de yapılabilir. İİAS ve biyopsi yöntemleri ile morfolojik olarak nodüllerin bir kısmına kolaylıkla tanı verilse de bazı lezyonların tanı kriterterleri tam oturmamıştır. Folliküler lezyonların davranışını belirlemede yeterli bilgi veren kesin morfolojik kriter yoktur. Diğer lezyonlarda morfolojik tanı daha kesindir tedavi ve davranışın belirlenmesinde önemli rol oynar. Hasta yönetiminde ince iğne aspirasyonu, kor biyopsi, frozen, moleküler yöntemlere karşın cerrahi materyalin histolojik değerlendirilmesi altın standarttır (Boerner ve Asa, 2010).

Tiroit karsinomunun moleküler temellerinin anlaşılması ve moleküler yöntemlerin İIAS ile elde edilen materyale uygulanarak daha doğru alt tiplendirme yapılabilmesi İIAS'yi daha değerli yapmaktadır. Böylece tiroit nodülü olan hastaların daha iyi yönetilebileceği yeni bir dönem başlamaktadır. Ayrıca bu bilgiler endokrin neoplazi sendromları için tarama yapılabilmesini ve tedavi için hedefler bulunmasını sağlamaktadır (Boerner ve Asa, 2010). Günümüzde kesin ayırıcı tanı için İİAS ve bunu takip eden cerrahi materyalin değerlendirilmesi standart uygulanan yöntemdir (Maitra, 2010).

Dondurulmuş (frozen) kesitler (DK)

Tiroit kitlelerinin cerrahisi sırasında sıklıkla DK yapıl- maktadır. Sıklıkla karsinomların tiroit dışı yayılımlarından ve metastatik lenf nodlarından DK istenir. Tanı bu lezyonlarda genellikle kolaylıkla verilir. Ancak Riedel tiroiditi, diffüz hiperplazide tiroit dışı büyüme ve sekestrize tiroit nodülü tanı sorunu yaratan lezyonlardır. En sık DK yapılan materyal nodül nedeni ile yapılan lobektomidir. Bunların küçük bir kısmı tek nodül olarak ortaya çıkmış granülomatöz tiroidit, Hashimoto tiroiditis veya malign lenfomadır. Ancak çoğunda ayırıcı tanı hiperplazide ortaya çıkan dominant nodül, adenom ve karsinom arasındadır. Deneyimli bir patolog, andiferansiye tiroit karsinom (UDC), kötü diferansiye tiroit karsinom (PDTC), yaygın invaziv folliküler karsinom, klasik papiller tiroit karsinom (PTC) ya da medüller tiroit karsinomu (MTC) tanısı vermede büyük bir zorlukla karşılaşmaz. Ancak dominant nodül, adenom, minimal invaziv folliküler karsinom, PTC folliküler varyant ve kapsüllü PTC'de tanı büyük bir problemdir. Kapsüler ve vasküler invazyon DK sırasında yapılan az sayıda örnek ile değerlendirilemeyebilir. PTC'un önemli bir özelliği olan buzlu cam görünümü frozen kesitlerde ortaya çıkmaz. Bu nedenle iyi diferansiye karsinomların önemli bir kısmının DK ile tanı alamayacağını cerrahın bilmesi gerekir. Ancak bu durum önemli bir tedavi sorunu yaratmamaktadır. Bu lezyonların önemli bir kısmı lobektomi ya da subtotal tiroidektomi ile tedavi edilebilmektedir.

İIAS'nin yaygın kullanılması ile DK ile cerrahinin yönlendirilmesi azalmaktadır. DK, papiller karsinom ve folliküler neoplazm tanısı alanlardan çok papiller karsinom şüphesi verilen olgularda faydalıdır. DK sirasında yapılan sitolojik preparatlar da tanıya önemli katkı sağlamaktadır (Rosai ve Tallini, 2011).

\section{Tiroit patolojilerinin tanısına sitolojik yaklaşım}

İnce iğne aspirasyonu yüzeyel olarak bakıldığında kolay bir yöntemdir. Ancak İİAS'nin en önemli problemi materyal yetersizliğinin yüksek oranda olmasıdır. İIAS yöntemi kolay olmakla birlikte yeterli örnekleme için tecrübe ve bazı doğru bilinen yanlışlardan kaçınmak gereklidir. Bu yanlışlar vakumun hücre toplanmasını sağladığı düşüncesi, kalın iğne kullanmak, agreziv aspirasyon tekniği ve aspirasyon sonrası kanama kontrolunun ihmalidir. Bunların sonucunda kanla dilüe ve yetersiz materyal elde edilir.

Yeterli materyal vakum uygulanan ve uygulanmayan yöntemlerle elde edilebilmektedir. İIAS ile doku elde etmenin tek yolu dokunun yapısını bozmak ve serbestleşen elemanları iğnenin içerisine alabilmektir. İğnenin keskin ve eğimli ucu dokunun serbestleşmesine epitelyal ve stromal elemanların iğnenin içerisine girmesine neden olur. İğne hareketi ile epitelyal hücreler stromal hücrelere göre daha kolay çevre dokudan ayrılır. İIAS' de biyopsi materyeline göre daha az stromal komponent gözlenir. Stromadan zengin dokular aspirasyona yeterli hücre vermezler. Yeterli materyal elde etmek için kanamaya neden olmamak ve iğne hareketi önemlidir. İğne içerisine materyalin alınabilmesi için lezyon içerisinde iğnenin çok sayıda ileri geri hareket etmesi gerekir. Sadece iğne batırarak vakum uygulamadan diğer elemanlarla karışmayan materyal elde edilebilir. Bu materyali yaymak zor olabilir. Kistik lezyonlarda tercih edilmemelidir.

İğnenin hareketi ile aspire edilen materyal iğnenin içini doldurur ve iğne ile enjektörün birleştiği alanda görülebilir hale gelir. Materyel buraya geldiği zaman aspirasyon tamamlanmış demektir. Materyal hızla görülür hale gelirse aspiras- 
yon travmatik demektir. Aspire edilen alan kan ile doludur ve yeterli materyal elde etme şansı düşüktür. Aspirasyon hemen durdurulmalı ve kanamayı durdurmak için basınç uygulanmalıdır. Daha sonra işlem tekrarlanmalıdır. Vakum doku üretiminde rol oynamaz, toplanan materyalin toplanmasına yardım eder. Solid organlarda sıvı, kan ve inflamasyon düşük dirençlidir. Vakum aspire edilen alandaki sıvının alınmasına neden olur. Aspire edilen materyalin dilüe olmasina da yol açabilir. İIAS yaparken kanamayı azaltmak için mümkün olan en ince iğne seçilmelidir. Palpable bir lezyon için önerilen iğne kalınlığı 27-25 gauge (G)'dir. 25 G lezyon içerisinde daha az eğildiği için daha avantajlıdır. Kalın iğnenin daha iyi materyal elde ettiği düşüncesi doğru değildir. Pratikte sıklıkla 21-22 G iğneler sıklıkla kullanılmaktadır. Bu iğneler ile bol hücre elde edilir ama örnekler kan ile dilüe olabilir. Aspirasyon sirasında lezyonun sabitlenmesi yeterli materyal elde edilmesinde önemlidir. Hareketli lezyonlara iğnenin girmesi zordur ve giren iğnenin hareketinin hücre serbestleştirici etkisi düşük olur. Lezyonu tam anlamı ile temsil edebilmesi için lezyonun farklı alanlarından birden çok aspirasyon yapılması gerekir. Her aspirasyonda yeni bir iğne kullanılarak lezyona girilir. Bir alandan gelen hücreler benign karekterde iken diğer alandan gelen hücreler tanısal olabilir. İdeal aspirasyon sayısı tatışmalıdır. Aspirasyon yapan kişinin tecrübesi, lezyonun boyutu, yapısı, gelen materyalin kalitesi, yeterlilik değerlendirmesi yapılıp yapılmaması bu sayıyı etkiler. Genellikle 2-3 aspirasyon yeterlidir. Ancak bazı lezyonlar için 5-6 girişim gerekir.

Ultrason (USG) eşliğinde yapılan aspirasyon lezyonun ve komşu yapıların daha iyi görülebilmesini ve küçük lezyonlara iğnenin girmesini sağlar. Ancak aspirasyon tekniğinde farkl1lık yoktur. Aspirasyonun iki komponenti vardır, hedeflenen lezyona girmek ve dokuyu örneklemek. Görüntüleme iğnenin doğru yerde olmasını sağlar ama yeterli örneklemeye katkı sağlamaz. En iyi yerleşmiş iğne bile aspirasyon doğru uygulanmaz ise materyal toplayamaz (Boerner ve Asa, 2010).

\section{Hasta başı yeterlilik değerlendirmesi}

Aspirasyon yapıldığı sırada preparatların hızla boyanarak değerlendirilmesidir. Yeterli örnek alındığından emin olmayı sağlar. Gereğinden az ya da fazla sayıda aspirasyon yapılmasını engeller. Lezyon hızla değerlendirilerek tanı için IHC, akım sitometrisi ve moleküler yöntemlerin uygulanması gerekiyor ise materyal bu yöntemler için uygun şekilde hazırlanır. Her aspirasyon sonrası verilen bilgi lezyona yapılacak diğer aspirasyonların metodunda düzeltmelerin yapılmasına yardımcı olur (Baloch ve LiVolsi, 2004; Burlingame ve ark., 2011).

Tiroit sitopatoloji raporlaması için Bethesda sistemi (BSRTC)

İIAS'nin başarısı hastalığın tipine, klinisyen ve patoloğun deneyimine, hekimlerin İIAS sınırlarının farkında olmalarına bağlıdır. İİAS'de amaç tüm tiroit kanserlerinin saptanması ve cerrahiye verilmesidir. $\mathrm{Bu}$ yapılırken de mümkün olduğunca az sayıda benign nodülün cerrahiye gitmesi sağlanmalıdır. İIAS'nin başarısında sitopatolog ile klinisyen arasındaki iletişim kritiktir. İletişimin sağlıklı olması için sitopatoloğun raporunun kısa, tüm klinisyenler tarafından anlaşılır, klinik olarak yol gösterici olması gerekir. Bethesda sistemi 2007 yılında yapılan geniş katılımlı bir toplantıda tiroit IIIAS rapor- larında terminoloji birliğinin sağlanması ve iletişimin doğru olması amacı ile geliştirilmiştir (Tablo 1) (Syed ve Cibas, 2010). Bu bölümde tanı kategorileri tek tek tartışılacaktır.

Tablo 1. Tiroit sitoloji raporlaması için Bethesda sistemi (BSRTC)

\begin{tabular}{|c|c|c|}
\hline Tanı Kategorisi & $\begin{array}{l}\text { Malignite } \\
\text { Riski (\%) }\end{array}$ & Klinik Yaklaşım \\
\hline Tanisal olmayan /Yetersiz & & US eşliğinde İİAS tekrarı \\
\hline Benign & $0-3$ & Klinik izlem \\
\hline $\begin{array}{l}\text { Önemi belirsiz atipi/Önemi belir- } \\
\text { siz folliküler lezyon }\end{array}$ & $\sim 5-15$ & İİAS tekrarı \\
\hline $\begin{array}{l}\text { Folliküler neoplazi/folliküler } \\
\text { neoplazi şüphesi }\end{array}$ & $15-30$ & Lobektomi \\
\hline Malignite Şüphesi & $60-75$ & $\begin{array}{l}\text { Totale yakın tiroidektomi/ } \\
\text { lobektomi* }\end{array}$ \\
\hline Malign & $97-99$ & $\begin{array}{l}\text { Totale yakın tiroidek- } \\
\text { tomi* }\end{array}$ \\
\hline
\end{tabular}

\section{A. Tanısal olmayan (nondiagnostik)/yetersiz}

Tiroit IIIAS'de literatürde yetersizlik \% 5-10 arasındadır. Hücresel ve kolloid içeriğin nitelik ve niceliği yeterliliği oluşturur. Lezyonun özellikleri ve aspirasyon tekniği yeterliliği etkiler. Materyalin yeterliliği sonucun güvenilirliğini belirler. Diagnostik bilgi sağlaması ve uygun klinik yaklaşım için İIAS altta yatan lezyonu ifade etmelidir.

$\mathrm{Bu}$ tanı kategorisi aşağıdaki durumlarda kullanılmaktadir.

- Sadece kist sivisı

- Hücre içermeyen materyal

- Diğer (kanlı materyal, pıhtılaşma vs gibi nedenlerle değerlendirme güçlüğü olanlar)

\section{Yeterlilik kriterleri}

Altı grup iyi korunmuş follikül hücre grubu olmalıdır. Her grup en az 10 hücreden oluşmalıdır. Bu hücrelerin tek lamda olması tercih edilir.

Bu kuralın istisnaları vardır.

- Sitolojik atipisi olan solid nodüller, bu nodüllerdeki şüpheli durum mutlaka belirtilmelidir.

- İnflamasyonu olan solid nodüller, lenfositik tiroidit, granülomatöz tiroidit, abse gibi durumlarda minimum follikül epitel hücre sayısı gerekmez. Bu lezyonlar benign olarak rapor edilir.

- Kolloid nodül, kolayca tanınan bol kolloid var ise bu lezyonlar benign olarak rapor edilir.

Tanisal olmayan materyel nedenleri

- On hücreden oluşan altı gruptan az iyi korunmuş ve boyanmış folliküler hücre bulunmaması

- İyi hazırlanmamış, boyanmamış ve iyi değerlendirilemeyen follikül hücreleri

- Kist sıvısı, on hücreden oluşan altı gruptan az iyi korunmuş ve boyanmış folliküler hücre içermiyor ise.

Basit ve üç cm altında kistik lezyonlarda malignite riski düşüktür. Sadece kist sıvısı aspire edilmiş ise kistik PTC olasılığı yalnızca sitoloji ile ekarte edilemez. Ancak kist benign özellikler taşıyor (USG) ise aspirasyon klinik olarak yeterli kabul edilebilir.

\section{Klinik yaklaşım}

Önceden yapılan İIAS'ne bağlı oluşabilecek reaktif değişiklikler malignite ile karışabileceği için üç aylık bir süreden sonra aspirasyon tekrarlanmalıdır. Tekrar İIAS, solid nodüller 
için USG ve yeterlilik değerlendirmesi eşliğinde yapılmal1dır. Tekrarlanan İ̇AS ile $\% 60$ oranında tanısal materyal elde edilir. İki kez uygun teknik ile ve deneyimli ellerde yapılan aspirasyonda tanisal olmayan materyal elde edilirse klinik duruma göre yakın takip ya da cerrahi yapılabilir. Kistik nodüllerde ise tekrar İIAS, USG şüpheli ise yapılmalıdır.

\section{B. Benign}

İIAS'nin klinik değeri benign lezyonları tanımadaki başarısından gelir. Benign lezyonlar tanıların yaklaşık \% 65'ini meydana getirir. Yanlış negatif oranı ideal olarak \% 2-3'ün altında olmalıdır.

Bu tanı kategorisi aşağıdaki durumlarda kullanılmaktadır.

- Benign folliküler nodül ile uyumlu (adenomatoid nodül, kolloid nodül, makrofolliküler adenom vs)

- Uygun klinik koşullarda lenfositik tiroidit (LT) ya da Hashimoto tiroidit (HT) ile uyumlu

- Granülomatöz (subakut) tiroidit (GT) ile uyumlu

- Diğer

\section{Graves hastalığı}

Fokal kromatin şeffaflaşması ve çentikli çekirdekler olabilir. Tedavi alan olgularda belirgin mikrofollikül formasyonları ve çekirdeklerde üst üste binme ve atipi görülebilir. $\mathrm{Bu}$ bulgular malignite ile karışabilir. Öykü ve alınan radyoaktif iyot tedavisinin bildirilmesi doğru değerlendirme için çok önemlidir.

\section{Lenfositik (Hashimoto) tiroiditi}

Polimorfik lenfoid hücreler ve Hürthle hücreleri ile karakterlidir. Dağınık hücrelerde çekirdek atipisi (anizonükleozis, şeffaflaşma ve çentikli çekirdekler) olabilir. LT bulguları var ise papiller tiroit karsinom (PTC) tanısı tüm bulgular olmadan verilmemelidir.

LT bulguları kesin değil ise PTC ile karışabilen çekirdek değişikliklerinin derecesine bağlı olarak önemi belirsiz atipi ya da malignite şüphesi tanısı verilebilir. Dominant monomorfik lenfoid hücreler gözlenir ise lenfoma şüphesi ortaya çıkabilir. Tanıyı doğrulamak için ek örnek alınarak flowsitometri çalışılması gerekir. Lenfositlerden fakir Hürthle hücrelerinin hakim olarak izlendiği örneklerde folliküler neoplazi Hürthle hücreli tip/folliküler neoplazi şüphesi, Hürthle hücreli tip tanısı düşünülebilir. Çıplak follikül epitel çekirdekleri lenfositler ile karışabilir ve yanlış LT tanısı verilebilir.

\section{Benign klinik yaklaşım}

En az 3-5 y1l süre ile 6-18 ay aralıklarla hastalar izlenir. Belirgin büyüme ve USG'de şüpheli bulgular var ise tekrar İIAS yapılması gerekir. Büyük, semptomatik, klinik ve USG olarak kaygı verici, karşı lobda maligniteye eşlik eden nodüllerde cerrahi yapılabilir.

\section{C. Önemi belirsiz atipi (AUS)/Önemi belirsiz follikü- ler lezyon (FLUS)}

Güvenle benign tanısı verilemeyen ancak folliküler neoplazi açısından şüpheli, malignite açısından şüpheli ya da malign kategorisine konamayacak kadar hafif sitolojik ya da yapısal atipi gösteren folliküler, lenfoid ya da farklı tipte hücrelerin var olduğu durumlar için kullanılan bir kategoridir. AUS kategorisine bir olgunun girmesini sağlayan çok sayıda durum olabilir. Bu nedenle raporda olası ayırıcı tanı ve öne- rilerin bulunması bu kategorinin raporlanmasında özellikle önemlidir.

\section{Klinik yaklaşım}

İIAS'lerin \% 3-18'i AUS olarak raporlanmaktadır. Tiroit İIAS'lerinde AUS oran $1 \% 7$ civarında olmalıdır. AUS tanısı alan olgular için yaklaşım klinik veriler ile raporda yapılan yorumun korelasyonu ve birçok olguda uygun süre sonra İIAS tekrarıdır. Tekrar yapılan İIAS'lerin çoğu daha kesin bir değerlendirmeye ulaşır ancak \% 20-25’i tekrar AUS olarak değerlendirilir. Klinik olarak riskli görülüp opere edilenlerde malignite riski \% 20-25'dir. Tüm grup düşünüldüğünde maliginite riski $\% 5-15$ 'e yakındır.

\section{Folliküler neoplazi şüphesi (SFN)/ Folliküler neop- lazi (FN) \\ Follliküler neoplazi şüphesi için farklı terminolojiler kul-} lanılmakta idi (folliküler lezyon, folliküler proliferasyon, kategorize edilemeyen gibi). Bu durum nodüler guatr, folliküler adenom, folliküler karsinomun birbiri ile çakışan sitomorfolojik özelliklerinin olmasından ve İ̇AS ile ayırd edilememesinden kaynaklanmaktadır. Ancak bazı sitolojik özellikler neoplazi şüphesini belirleyebilir. IİAS malignite olasılığı fazla olan nodülleri ayırmada bir tarama testidir. Amaç tüm potansiyel folliküler karsinomları yakalamaktır. Kesin tanı lobektomi materyalinde kapsül ve damar invazyonu araştırılarak verilebilir.

$\mathrm{Bu}$ grubun \% 35'i hiperplastik nodül olduğu için SFN isim olarak tercih edilmelidir. Unutulmamalı ki bu gruptaki sitolojik-histolojik uyum histolojik tanının tekrarlanabilirliğinin düşüklüğü nedeni ile de gölgelenmektedir. Eğer çekirdeklerde PTC bulguları var ise malign/malignite şüphesi tercih edilmeli, SFN kullanılmamalıdır. Paratiroit adenomları tiroit İIAS olarak gönderilirler ise FN/SFN rapor edilirler.

\section{Klinik yaklaşım}

$\mathrm{Bu}$ gruba giren hastaların çoğuna cerrahi yapılmaktadır. Hemitiroidektomi ya da lobektomi en sık uygulanan cerrahi tipidir. Olguların \% 65-85'i neoplastik, \% 12-32'si maligndir. Malignlerin \% 27-68'i PTC'dir. Bu durum papiller özelliklerin İIAS'de belirgin olmamasından ya da histolojik olarak PTC folliküler varyant, folliküler karsinom ayırıcı tanı güçlügünden kaynaklanabilir.

Folliküler neoplazi şüphesi, Hürthle hücreli tip (SFNHTC)/Folliküler neoplazi, Hürthle hücreli tip

$\mathrm{Bu}$ gruba giren lezyonların \% 16-25 oranında neoplastik olmaması nedeni ile SFNHCT tercih edilen terimdir. Hürthle hücre (HC) ince granüllü geniş sitoplazmalı follikül hücreleridir. LT, mutinodüler guatr (MNG), $\mathrm{HC}^{\prime}$ li adenom, $\mathrm{HC}^{\prime}$ li karsinomlarda bulunur. Hürthle hücreler birçok ayırıcı tanı güçlüğüne neden olur. MNG, LT, hiperplastik $\mathrm{HC}$ nodül SFNHCT ya da AUS olarak tanımlabilir. Raporda açıklamanın olması önemlidir. Bu grup için tekrar IİAS ek bilgi vermez. Klinik korelasyon gereklidir. Onkositik diferansiasyon gösteren PTC, SFNHCT ya da malignite şüpheli olarak tanımlanabilir. Bu grup için de raporda açıklamanın olması önemlidir. Medüller tiroit karsinomu ve paratiroit tümörleri de bu grup içinde yer alabilir. IHC, klinik, radyoloji ayırıcı tanı da yardımcı olabilir. 


\section{E. Malignite şüphesi}

Folliküler ve Hürthle hücreli karsinom dişında primer tiroit karsinomları İİAS ile kolayca tanınabilir. Malignite bulgularının bir kısmı var ancak kesin tanı için yeterli değil ise bu tanımlama kullanılır. Bu durumun en önemli nedenleri

- Suboptimal örnekleme, fiksasyon

- PTC ve MTC'nin varyantları

- LT/PTC ve LT/ MALT lenfoma arasında örtüşen sitomorfolojik bulgular olmasıdır.

Raporda PTC şüphesi, medüller tiroit karsinom şüphesi, metastatik karsinom şüphesi, lenfoma şüphesi ya da diğer patolojiler belirtilmelidir. Bu kategori klinisyene alternatif tedavi olasılıkları için olanak verir.

\section{Malignite şüphesinde klinik yaklaşım}

- PTC şüphesi: Cerrahi +/- DK tercih edilen yaklaşımdır. İIAS en az DK kadar sensitiftir.

- MTC şüphesi: Tekrar İİAS hücre bloğunda İHC ile kalsitonin çalışılması ya da serum kalsitonin düzeyi çalışılması

- Lenfoma şüphesi: Tekrar İIAS örneğinde akım sitometri ile lenfoid hücrelerin monoklonalitesi araştırılmalıdır.

- Malignite şüphesi: Klinik+tekrar İİAS hücre bloğunda İHC

\section{F. Malign}

Tiroit İIAS'lerinin \% 4-8'i maligndir. Bunların çoğu PTC'dir.

PTC: İİAS ile PTC tanısı alanların \% 96-100'ü ameliyat sonrası histolojik olarak PTC tanısı alırlar. İIAS'de PTC için tipik tanımlanan tipik çekirdek özellikleri olsa da bunlar bir arada ve yaygın ise tanısaldır. Çekirdek yerleşimli sitoplazmik pseudoinkluzyon, PTC'lerin \% 50-100'ündebulunur. Ancak MTC, PDTC, UDC, nodüler guatr, folliküler adenom, LT de de bulunabilir.

Çentikli (Groove) çekirdekler: PTC, MNG, LT, Hürthle hücreli neoplazi de olabilir. Psammom cisimciği, MTC, LT, Graves hastalığı, MNG'de de bulunabilir.

MTC: Ayırıcı tanıda HCN, PTC, UTC, plazmasitom, hiyalinize trabeküler adenom, metastaz yer alır. MTC tanısı sitoloji ile düşünülür. Hücre bloğunda İHC ile kalsitonin ve Kongo kırmızısı ile amilod araştırılarak ya da serum kalsitonin düzeyi yüksekliği gösterilerek kesinleştirilir.

PDTC: İIAS bulguları spesifik değil. 40 olguluk seride raporlanma şekilleri, \% 42,5 SFN, \% 32 PDTC, \% 10 karsinom, \% 15 PTC olarak dağılım göstermektedir. Ayırıcı tanıda metastaz ve MTC bulunur.

UTC: Yüksek dereceli, pleomorfik, epitelyal kökenli epiteloid ve/veya iğsi özellikler gösteren tümördür. Sellülarite değişkendir. Sarkom ve metastazlarla (melanom, sarkomatoid renal hücreli karsinom, akciğer karsinomu) ayırıcı tanı yapılmalıdır. İHC, USG, klinik bulgular bu konuda yardımcı olan yöntemlerdir (Syed ve Cibas, 2010).

\section{Tiroit lezyonlarının patolojisi \\ Konjenital anomaliler \\ Tiroglossal duktus anomalileri}

Tiroglossal duktus anomalileri tiroglossal duktusun lokalize olarak kalmasıdır. Foramen cecum yada suprasternal çentik ile ilişkili sinüs ya da kör tubuler bir yapı şeklinde olabilir. Döşeyen hücrelerin sekresyonuna bağlı kistik yapı halini alabilir. Buna tiroglossal kist denir. Boyun orta hatta hiyoid kemik bölgesi en sık yerleşim bölgesidir (Rosai ve Tallini, 2011). Kist skuamoz ve silyalı solunum yolu epiteli ile döşelidir. Kiste komşu stromada müköz gland ve tiroit follikülleri bulunur. İIAS'de kolloid içermez ya da akışkan kolloide benzeyen ince proteinöz sıvı bulunur. Kist içeriğinde vakuole makrofajlar vardır. Skuamoz ve silyalı solunum yolu epiteli bulunabilir. Genellikle epitelyal hücreler gözlenmez. Follikül epitel hücreleri de genellikle yoktur. Eğer var ise benign karakterdir. Bu kistlerin tanısını sadece sitoloji ile vermek mümkün değildir. Klinikopatolojik korelasyon tanıyı düşündürür. Tiroglossal duktus kistinden kaynaklanan tiroit karsinomu ayırdedilmelidir. Papiller karsinom burada sıktır. Biyopside papiller karsinom mevcutsa tiroit ya da tiroglossal kist kökenli olabileceği gibi tiroit komşuluğunda bulunan orta hat lenf noduna metastaz olma olasılığ 1 da vardır (Boerner ve Asa, 2010). Kistin tedavisi cerrahi olarak lezyonun çıkarılmasıdır. Rekürrens olmaması için hyoid kemiğin orta 1/3'ünü içermelidir (Rosai ve Tallini, 2011).

\section{Heterotopik tiroit dokusu}

En sık lokalizasyon dil tabanıdır. Kapsüllü ya da dil kasları arasında kapsülsüz olarak bulunabilir. Bu durumda bir invaziv tümörü taklit edebilir. Diğer lokalizasyonlar, dilin anteriyoru, submandibular bölge, larinks, trakea ve mediasten ve kalptir. Duodenum, safra kesesi, adrenal bez gibi birçok odakta da bulunduğu bildirilmiştir (Rosai ve Tallini, 2011).

\section{Brankial yarık anomalileri}

Tiroit ile yakın ilişkili bir yapıdır. Anomalileri fistül, basit sinüs, kist ya da kıkırdak adacığı şeklinde olur. Boynun anterolateral kısmında bulunur. Tiroit içerisinde bulunabilir. $\mathrm{Bu}$ kistler skuamoz epitel ile döşelidir. Kolumnar epitelde bulunabilir. Duvarında germinal merkezleri belirgin lenfoid agragatlardan oluşan lenfoid doku bulunur. Aspirasyonda skuamoz hücreler ve lenfositler gelebilir (Boerner ve Asa, 2010; Rosai ve Tallini, 2011). Nadiren skuamoz karsinom bu kistlerden gelişebilir. Kist duvarında bulunan ektopik tiroit dokusundan papiller karsinom gelişme olasılığ 1 vardır. Ancak lateral boyunda kistik bir yapıda bu karsinomlar gözleniyor ise öncelikle metastaz olma olasılığı araştırılmalıdır (Rosai ve Tallini, 2011).

\section{Faringeal ya da ösefageal divertikül}

Tiroit içerisinde kitle olarak ortaya çıkabilirler. Ultrasonografi ile anatomik kökeni genellikle gösterilir. Eğer gösterilemez ise İIAS yapılır. Skuamoz hücreler, makrofajlar, yiyecek artıkları görülebilir (Boerner ve Asa, 2010).

\section{Tiroidit}

\section{Akut tiroidit}

Enfeksiyon, travma, radyasyon, tümör nekrozuna bağl1 olabilir. Enfeksiyon sosyoekonomik olarak ileri ülkelerde azdır. Fistül gibi yapısal anormalliklere eşlik eder. İmmünyetmezliği olan kişilerde görülülebilir (Boerner ve Asa, 2010). En iyi tanı yöntemi İİAS ve kültürdür. İİAS'de akut inflamatuar hücreler, makrofajlar, nekrotik kırıntılar, granülasyon dokusu görülür. Kültür ve mikroorganizmalar için boya yapılmalıdır. Anaplastik tiroit karsinomu geniş nekrozlara neden olduğu için akut inflamasyon ile karışır (Boerner ve Asa, 2010; Rosai ve Tallini, 2011). 


\section{Granülomatöz (subakut) enflamasyon}

Granülomatöz enflamasyon De Quervain tiroiditi, palpasyon tiroiditi, sarkoidoz ve enfeksiyona bağlı olabilir (Boerner ve Asa, 2010). İİAS'de granülomatöz inflamasyon, follikül epitel hücreleri ve kolloid bulunur. De Quervain tiroiditi ve palpasyon tiroiditinde kolloid içeren multinükleer dev hücreler bulunur. Nekroz var ise enfeksiyona bağlı granülom daha çok düşünülmelidir (Boerner ve Asa, 2010). De Quervain tiroiditinde makroskobik olarak tüm tiroit asimetrik olarak etkilenmiştir. Tiroit serttir, çevreye yapışıklık göstermez. Palpasyon tiroiditi ise klinik bulgu vermez. Makroskopide belirgin bir lezyon yoktur. Tiroit folliküllerinin içinde histiyosit, dev hücreleri ve lenfositlerin birikmesi ile karekterlidir. İnflamasyon zamanla follikül çevresine uzanır (Boerner ve Asa, 2010; Rosai ve Tallini, 2011).

\section{Riedel tiroidit}

İleri ve orta yaşta görülür. Kadınlarda biraz daha fazladır. Sert tiroit dokusu ile karekterli nadir fibroinflamatuar lezyondur. Trakeaya bası yapar. Kronik inflamatuar infiltrat tiroidi ve çevre dokuları etkiler. Tiroit çevre dokulara yapış1klık gösterir. Makroskopik olarak tiroidde lokalize alanlar1 etkiler asimetriktir. İnflamatuar infiltrat lenfosit, monosit ve granülositlerden oluşur. Granülom, dev hücreler, lenfoid follikül ve Hurthle hücre bulunmaz (Boerner ve Asa, 2010; Rosai ve Tallini, 2011). İIAS genellikle hücre içermez, reaktif atipi yanıltıcı olabilir. Ayırıcı tanıda kronik lenfositik tiroidit, sklerozan papiller karsinom, anaplastik karsinom, lenfoma bulunur (Boerner ve Asa, 2010).

\section{Otoimmün tiroit hastalıkları}

Otoimmün tiroiditler (lenfositik tiroidit, Hashimoto tiroiditi) ve Graves hastalığı bu gruba girer. Her iki hastalığın bulgularını içeren olgular bulunmaktadır (hashitoksikozis).

İmmün kökenli hasar başlangıçta diffüz ya da nodüler hiperaktiviteye yol açar. Daha sonra gland tükenir ve atrofiye gider. Follikül epitelinde oksifili görülür. Otoimmün tiroit hastalığının en sık bulgusu germinal merkez oluşturan yoğun lenfoid hücre infiltrasyonudur. Aradaki folliküllerin durumu hastalığın tipini belirler. Graves hastalığında folliküller diffüz hiperplastik, lenfositik tiroiditte relatif olarak normal, Hashimoto tiroiditinde ise onkositik tiptedir. Pratikte lenfositik ve Hashimoto tiroiditini sinonim olarak kullanan otoriteler vardır ancak bu morfoloji ve tiroit fonksiyonları arasında iyi bir bağlantı olduğu için önerilmemektedir. Lenfositik tiroidit daha sık olarak çocuklarda görülür ve sıklıkla iğne biyopsisi ile tanı alır. Jüvenil form otoimmün tiroidit olarak da adlandırılır. Makroskobik olarak tiroit diffüz büyüktür kesit yüzü solid, beyaz ve nodülerdir. Hashimoto tiroiditi (HT) ise daha çok 40 yaş üzeri kadınların hastalığıdır. Tiroit diffüz olarak sert ve büyüktür. Çevre dokulara yapışıklık göstermez.
Bazen bir lob daha büyük olabilir ya da multinodüler özellik gösterebilir. Kesit yüzü kolay parçalanabilen, nodüler, sarı-gri lenf noduna benzer özelliktedir. Kolloid seçilemez. Diffüz bir hastalık olsa da makroskobik ve mikroskobik olarak nodülarite olabilir. Nodüllerin epitelyal komponenti hiperplastik kalitededir. Bu durum HT ve nodüler hiperplazi olarak ifade edilebilir. Ancak bu iki bulgu patojenik olarak ilişkili olduğu için nodüler HT olarak adlandırmak daha uygundur. Bu durumun bazı varyasyonları vardır. Bir ya da iki adet solid ya da folliküler yapılar şeklinde düzenlenen Hürthle hücrelerinden oluşan nodül hiperplastik (dominant) nodül olabilir. Bunların bir kısmı kalın bir kapsül içerir. Neoplastik oldukları tartışmalı olsa da folliküler adenom için gerekli tüm kriteleri tamamlarlar (Rosai ve Tallini, 2011). Mikroskobik değerlendirmede germinal merkez oluşturan lenfoid infiltrasyon gözlenir. Tiroit follikül epitel hücreleri kolloidden fakir atrofik olabilir ya da onkositik metaplazi gösterir. Belirgin düzensiz çekirdek zarı, çentik ve çekirdek şeffaflaşması ile karekterli papiller karsinomu taklit eden sitolojik atipi görülür. Hastalık ilerledikçe fibrozis belirginleşir. Lenfositik infiltrasyon daha az belirgin hale gelir, skuamoz metaplazi görülür (Boerner ve Asa, 2010).

İIAS'de; lenfoid hücrelerin yoğun olması tipiktir. Çok sayıda lenfoid hücre, tiroidin kronik inflamasyonuna, periferal kan ile aspiratın dilüe olmasına, peritiroidal lenf nodu aspire edilmesine ve lenfomaya bağlı olabilir. Az sayıda lenfoid hücre var ise bunun hemodilusyona $\mathrm{m} ı$ inflamasyona $\mathrm{m} ı$ bağlı olduğunu ayırd etmek güçtür. Kronik lenfoid hücre infiltrasyonunu lenf nodundan ayırdetmek zordur. Tiroit epitelinin ve koloidin varlığı tiroidin örneklendiğini gösteren bulgulardır. LT'de tiroit follikül epitel hücreleri sakindir. HT'de Hürthle hücreler sıklıkla bulunur. Hürthle hücreler metaplastik hücrelerdir. Sitoplazmaları geniş, mitokondri artışına bağlı olarak eosinofilik ve granülerdir. Hashimoto tiroiditi dışında birçok durumda da görülebilirler (Boerner ve Asa, 2010). HT'de kolloid kaybına bağlı olarak epitel sinsityal görülebilir. Epitel tabakaları içerisinde vasküler yapılar olmaz. Hürthle hücrelerinde ve normal follikül epitel hücrelerinde kromatin irregüler, soluk ve granülerdir. Çekirdek düzensizlikleri ve çentikler s1k bulgu olup, nükleol belirgindir. Bu değişiklikler papiller karsinomu taklit eder. Lenfositik tiroidit var ise kesin papiller karsinom tanısı için tüm kriterlerin bir arada olması gerekir (Boerner ve Asa, 2010). HT komplikasyonları, malign lenfoma lösemi, papiller karsinom ve Hürthle cell neoplazilerdir. Özellikle başlangıç aşamasında bunların ayırıcı tanısı çok güçtür. HT’de folliküler hücreler proliferatif nodüller oluşturduklarında tümör süpresör gen lokusunda heterozigisiteyi kaybedebilir ve karyotipik olarak anormal olabilirler. HT follikül hücrelerinde çekirdekte şeffaflaşma üst üste binme gibi bulgular görülür. Bunların papiller karsinomun preneoplastik bulguları olup olmadığı merak konusudur.

\section{Tablo 2. Hiperplastik hastalıkların majör formları}

\begin{tabular}{llll} 
İsim & Mekanizma & Patoloji & Fonksiyon \\
\hline Dishormonogenetik guatr & Tiroit hormon metabolizmasında genetik hata & $\begin{array}{l}\text { Nodüler ya da daha az olarak diffüz } \\
\text { hiperplazi }\end{array}$ & Hipotiroit \\
Graves hastalığı & Otoimmün & Diffüz hiperplazi & Hipetiroit \\
$\begin{array}{l}\text { Nodüler hiperplazi } \\
\text { Endemik guatr }\end{array}$ & İyot yetersizliği & Nodüler hiperplazi & Genellikle ötiroit bazen hipotiroit \\
Sporadik guatr & Bilinmeyen & Nodüler hiperplazi & $\begin{array}{l}\text { Genellikle ötiroit bazen hipotiroit ya da } \\
\text { hipertiroit }\end{array}$ \\
\hline
\end{tabular}


RET/PTC HT ve papiller karsinom arasında bir ilişkiye işaret ediyor olabilir. Düşük düzey RET/PTC rearanjmanı HT'de sıklıkla saptanabilir. Bu nedenle papiller karsinoma moleküler tanı koymaktan kaçınmak gerekir. Az sayıda hücrede görülen değişiklikler papiller karsinomu işaret etmek zorunda değilidir. BRAF mutasyonları HT' de saptanmamıştır (Rosai ve Tallini, 2011).

\section{Hiperplazi}

Hiperplazi oluşum mekanizmalarına morfolojik özelliklerine ve klinik bulgularına göre sınıflanır. Pratikte üç önemli tipi vardır (Tablo 2) (Rosai ve Tallini, 2011).

\section{Dishormonogenetik guatr}

Gland büyük ve multinodülerdir. Mikroskopik olarak solid ya da mikrofolliküler içeren hücreden zengin nodüller içerir ve fibrozis sıktır. Çekirdek atipisi ve mitoz görülür. $\mathrm{Bu}$ hastalarda karsinom rapor edilmiştir ve çoğu folliküler tiptedir. Ancak atipi görülmesi nedeni ile karsinom tanısı verirken çok dikkatli olmak gerekir (Rosai ve Tallini, 2011).

Graves hastalığı (Basedow hastalığı, diffüz toksik guatr)

Gland hafif ve orta derecede diffüz büyümüştür. Kesit yüzü kırmızı ve gridir. Uzun süren olgularda gland parçalanabilen kıvama gelir. Soluk sarı renklidir. Mikroskobik olarak folliküller hiperplastiktir. Papiller karsinom ile ayırıcı tanı güçlüğü yaratabilen papiller yapılar oluşturur. HT'ye ilerlemenin bir göstergesi olarak değişen miktarda oksifilik hücre bulunur. Stromada germinal merkez oluşturan lenfoid hücreler bulunur. Uzamış olgularda fibrozis olabilir. Tiroit dışında bazen çizgili kaslar arasında hiperplastik folliküller bulunabilir. Malignite ile karıştırılmamalıdır.

Nodüler hiperplazi (nodüler ya da multinodüler guatr, adenomatoid guatr, adenomatöz hiperplazi)

En sık tiroit hastalığıdır. İki tipi vardır.

Endemik Guatr: Hormon üretimindeki yetersizlik TSH artışına neden olur. Kolloidden fakir hiperaktif tiroit dokusu oluşur (parenkimatöz guatr). Daha sonra nodül oluşumuna eşlik eden veya etmiyen koloid birikimi ve folliküler atrofi ortaya çıkar (diffüz veya nodüler koloidal guatr).

Sporadik (nodüler) guatr: Bazı olgular LT ve HT'ye eşlik eder. $\mathrm{Bu}$ hastalığın nodüler formu olarak görülebilir. Klinik olarak hastaların çoğu multinodülerdir ve tiroit çok büyük olabilir. Tek, sert, dominant nodülü olanların klinik olarak maligniteden ayırılması çok zordur.

Makroskopik olarak kesit yüzünde bir kısmı kapsüllü çok sayıda nodül bulunur. Kanama, kalsifikasyon, kistik dejenerasyon sıktır. Mikroskopik olarak çok farklı görüntüler ortaya çıkar. Çok sellüler olabilir ya da dilate büyük folliküller içerir. Hürthle hücreleri bulunabilir. Papiller yapılar olabilir ve bu papiller karsinom ile ayırıcı tanı zorluğu yaratır. Nodül içerisinde büyük dilate folliküller yanı sıra iyi sınırlı solid ya da mikrofollikül yapan hücre kümeleri bulunur. Nodüler guatrların bu kümelerin epizodik çoğalması ile büyüdüğü düşünülmektedir. $\mathrm{Bu}$ odaklar sekonder proliferasyon fokusu olarak adlandırılır. Bu odaklarda immünhistokimyasal olarak c-Ras ve p21 protoonkogen ürünleri gösterilir. Folliküllerin yıkılması ile granülomatöz reaksiyon oluşabilir. Değişen de- recelerde kronik inflamatuar hücreler birçok olguda bulunur. Yüksek derecede atipi gösteren hücrelerin varlığı radyoaktiviteye maruziyeti gösterir.

Dominant nodül ile gerçek adenomu ayırmada bazı kriterler vardır. Adenom genellikle tektir ve kapsülle çevrilidir. Normal glanddan farklı genellikle küçük folliküllerden oluşur ve çevreye bası yapar. Nodüler hiperplazide ki nodüller ise genellikle birden çoktur. Kapsül tam değildir. Çevre dokulara bası yoktur. Özellikle adenom özellikleri taşıyan lezyon multiple ise ya da nodüler hiperplazi zemininde ise ayırım imkansız olabilir. Daha önce yapılan çalışmalardan farklı olarak son çalışmalarda X kromozom inaktivasyon paternine göre nodüler hiperplazide bulunan dominant nodüllerin önemli bir kısmının monoklonal, morfolojik olarak adenom olan lezyonların ise küçük ama belirgin bir kısmının poliklonal olduğu gösterilmiştir. Birçok hiperplastik nodül normal karyotiplidir. Ancak küçük bir kısmında özellikle de adenomatöz özelliklilerde olanlar kromozom 7'nin ekstra bir kopyası bulunur. TSRH aktive gen mutasyonları, RAS mutasyonları hiperplastik nodüllerde bulunabilir. Bu bulgularla hiperplastik nodüllerin aslında neoplastik olabileceği tartış1labilir ve bunlar bize neoplazi ve hiperplazi arasında bir sınır çizmek zor olduğunu göstermektedir. Şu an için adenom ve nodül ayırımında genetik patoloji klasik histolojiden daha iyi değildir. Nodüler hiperplazinin karsinom riski artışı ile ilişkisi de henüz açık değildir. Ancak böyle bir artış varsa bile pratik amaçlarla göz ardı edilebilecek kadar küçüktür (Rosai ve Tallini, 2011).

\section{Tümörler}

\section{Epidemiyoloji}

Tiroit kanseri gelişmiş ülkelerdeki malignitelerin \% 1'ini oluşturur. Dünyada tahmin edilen yıllık insidans 122.000 olgudur. Benign tümörler sıktır. Malign tümörler relatif olarak az görülmelerine karşın endokrin sistemin en sık karşılaşılaş1lan tümörleridir (DeLellis ve Williams, 2004). Klinik olarak saptanan neoplazilerin çoğu primer ve epitelyaldir. Geleneksel olarak adenom ve karsinom olarak adlandırılırlar. Tiroit neoplazileri hücre tiplerine göre üç ana grup altında incelenebilir.

1. Folliküler hücre diferansiasyonu gösterenler (lezyonlarin $\% 95$ ' ten fazlası bu gruba girer)

2. C- hücre diferansiasyonu gösterenler

3. Folliküler ve C-hücre diferansiasyonu gösterenler (Rosai ve Tallini, 2011).

Folliküler orjinli karsinomların çoğu yavaş seyirlidir. On yıllık yaşam \% 90'ın üzerindedir. Primer lenfomalar sık görülmez, diğer epitelyal olmayan maligniteler çok nadirdir.

\section{Yaş ve cinsiyet}

Tiroit karsinomu genç ve orta yaşlı erişkinlerde görülür. Çocuklarda nadirdir. Ortalama tanı yaşı papiller karsinom için orta 40 ve erken 50'li, folliküler ve medüller karsinom için 50'li yaşlar, az diferansiye ve anaplastik karsinom için 60'lı yaşlardır. Birçok çalışmaya göre kadınlarda erkeklere göre 2-4 kat fazladır. Ancak çocuk ve yaşlılarda cinsiyet farkı belirgin değildir (DeLellis ve Williams, 2004).

\section{Coğrafi dağılım}

İyot eksikliği ile folliküler ve anaplastik karsinom insidans artışı arasında ilişki vardır. İlginç olarak bu bölgelerdeki 
tiroit tümörlerinde RAS onkogen mutasyonları daha sıktır. İyot eksikliği olan bölgelerde papiller karsinom predominanttır (Rosai ve Tallini, 2011). Tiroit karsinomu insidans1 birçok ülkede 1970'lerden beri giderek artmaktadır ancak bu kansere bağl1 mortalite düşmektedir (DeLellis ve Williams, 2004).

\section{Klasifikasyon}

Geleneksel olarak tiroit karsinomlarının majör grupları, papiller, folliküler, medüller, andiferansiye (anaplastik) karsinomdur. Bu sinıflama ileri moleküler tekniklerce de desteklenmektedir. Dört grubun her birinde bir miktar çakışmalar olsa da belirli genler etkilenmektedir. Ancak bazı alanların hala aydınlatılmaya ihtiyacı vardır. Papiller karsinomun folliküler varyantı folliküler tümörlerle benzer onkogen değişikliklerini gösterir. Familyal adenomatöz polipozisli hastalarda görülen morfolojik olarak farklı grup papiller komponenti de içeren farklı patternler içerir. Papiller karsinomların içinde kabul edilirler. Nadir görülen skuamoz ve mukoepidermoid karsinomlar major tiplerin bir alt grubu olarak kabul edilemez. Klinik farklılıkları yüzünden diğerlerinden farklı tedavi edilirler. Az diferansiye karsinomlar papiller ya da folliküler karsinomdan dediferansiye oldukları yönünde bulgular taşıyabilirler. Klinik farklılıkları yüzünden diğerlerinden farklı tedavi edilirler. Onkositik tiroit tümörleri özel bir problem doğurur. Geleneksel olarak folliküler grubunda kabul edilirler. Bu tümörler solid, folliküler ve papiller yapılar içerebilir. Sadece papiller karsinomun nükleer özellikleri var ise papiller karsinom olarak adlandırılırlar.

\section{Tablo 3. Tiroit tümörlerinin histolojik WHO sınıflaması (2004)}

\begin{tabular}{l} 
Tiroit kanserleri \\
\hline Papiller karsinom \\
Folliküler karsinom \\
Az diferansiye karsinom \\
Andiferansiye (anaplastik) karsinom \\
Skuamoz hücreli karsinom \\
Mukoepidermoid karsinom \\
Eosinofili ile birlikte sklerozing mukoepidermoid karsinom \\
Müsinöz karsinom \\
Medüller karsinom \\
Miks medüller ve folliküler hücreli karsinom \\
Timus benzeri diferansiasyon gösteren spindle hücreli tümör \\
Timus benzeri diferansiasyon gösteren karsinom \\
Tiroit adenomu ve ilişkili tümörler \\
\hline Folliküler adenom \\
Hiyalinize trabeküler tümör \\
Diğer tiroit tümörleri \\
\hline Teratoma \\
Primer lenfoma ve plazmasitoma, Ektopik timoma \\
Angiosarkoma \\
Periferal sinir kılıfi tümörleri \\
\hline
\end{tabular}

Gen spesifik onkositik tümör henüz tanımlanmamıştır. Herediter non-medüller tiroit karsinomu bir grup sendromu içerir. Bunların farklı genetik profili, farklı davranışı ve bazı olgularda karekteristik morfolojileri vardır.

\section{Mikrokarsinom}

Bir santimetre ve daha düşük çaplı papiller karsinomları olan hastaların yaşam süreleri normal populayondan farklı değildir. Palpasyon yerine ultrasonografi ve İIAS kullanılması ile mikrokarsinomlar cerrahi uygulanan tiroit karsinomlarının daha büyük kısmını oluşturmaya başlamışlardır. Günümüzde $2004 \mathrm{WHO}$ sinıflaması tiroit kanserleri için yaygın olarak kullanılmaktadır (Tablo 3).

\section{Etiyoloji ve patogenez}

Papiller karsinom gelişiminde çevre, genetik ve hormonal faktörler rol oynar. Tiroit çevrede iyotu alır ve radyoaktif iyotun genotoksik (DNA hasarı) etkisine açıktır. Aynı şekilde iyot yetmezliğinde TSH'nın nongenotoksik (stimulan) etkisine de açıktır. Radyasyon folliküler adenom ve karsinom gelişmesinde de rol oynar. Papiller karsinomlardan daha az sıklıktadırlar ve muhtemelen daha uzun latent periyotları vardır. Çernobil kazasından sonra Belarus ülkelerinde çocuklarda tirod karsinom riski artmıştır. Bu artış radyasyon ile karşılaşma yaşı küçüldükçe daha da artmaktadır. Papiller karsinom eksternal radyasyon ve radyoaktif iyot ile alınan internal radyasyon ile en yakın ilişkili tipdir. Süt radyoaktif iyotun insan besin zincirine karışma yoludur. Küçük çocuklar daha çok süt tüketir ve radyoaktif iyot uptake'i erişkinlerden daha fazladır. Radyasyon DNA'da çift zincir kırıklarına neden olur. RET ve TRK rearanjmanları için öncüldür. Bu da papiller karsinom gelişmesinin nedeni olabilir.

Folliküler karsinom etyolojisi papiller karsinom ile benzerlik gösterir. Ancak folliküler karsinom özellikle iyot yetersizliği ile ilişkilidir. İyot yetersizliği ve genetik etkiler nodüler guatr ile arasındaki bağlantıyı sağlayabilir. Dishormonogenezis ve Cowden sendromunda çok sayıda adenom ve folliküler karsinom gelişebilir. Lenfositik tiroidit ve papiller karsinom ile belirgin birliktelik vardır (DeLellis ve Williams, 2004).

\section{Genetik yatkınlık}

Medüller karsinomun ailevi olduğu iyi bilinmektedir. Olguların \% 25'i sendromlarla ilişkilidir. Bu olgularda RET onkogeninde germ line mutasyon vardır. Papiller karsinomda da güçlü ancak tam olarak açıklanamamış bir ailevi faktör vardır.

\section{Onkogenler ve tiroit karsinomları}

Sıklıkla radyasyona bağlı DNA'da çift zincir kırıkları RET ve TRK rearanjmanları papiller karsinom için karekteristiktir. Birçok çalışmada RET rearanjmanları ve BRAF mutasyonlarının papiller karsinomlar için özel olduğu belirtilmiştir. Folliküler adenom ve karsinomlar sıklkkla RAS mutasyonları gösterirler. Folliküler karsinomlar ve adenomların küçük bir kısmı PAX8/PPAR $\gamma$ rearanjmanı gösterir. RET germline mutasyonları ailevi medüller karsinom, somatik mutasyonlar ise sporadik medüller karsinomlarda görülür. Bu nokta mutasyonları ve küçük papiller karsinom rearanjmanlarından farklıdır. TP53 mutasyonları andiferansiye tiroit karsinomunun en sık görülen moleküler özelliğidir. Az diferansiye ve andiferansiye karsinomların bir kısmında papiller karsinom orjinleri ile uyumlu olarak BRAF mutasyonları olabilir (DeLellis ve Williams, 2004). 
Tablo 4. Tiroit karsinomları için TNM klasifikasyonu (DeLellis ve Williams, 2004)

T-Primer tümör

TX Primer tümör değerlendirilemeyen

T0 Primer tümör bulgusu yok

T1 Tümör büyük çapı $2 \mathrm{~cm}$ 'den küçük tiroide sınırlı

T2 Tümör $2 \mathrm{~cm}$ 'den büyük $4 \mathrm{~cm}$ 'den küçük, tiroide sınırlı

T3 Tümör 4 cm'den büyük, tiroit içine sınırlı ya da minimal tiroit dışı yayılım gösteren (sternohiyoid kasa yayılım, peritiroit yumuşak dokulara)

T4a Tiroit kapsül dışına uzanan ve subkutanöz yumuşak dokuları, larinks, trakea, yemek borusu, rekürren laringeal siniri invaze eden, herhangi boyda tümör

T4b Prevertebral fasiya invazyonu yapan, karotid arteri ya da mediastinal damarları çevreleyen, tümör

Tüm anaplastik (andiferansiye) tümörler T4 kabul edilir

T4a Cerrahi olarak çıkarılabilen tiroit içi anaplastik karsinom

T4b Cerrahi olarak çıkarılamayan ekstratiroit uzanımlı anaplastik karsinom

Multi fokal tümörleri belirtmek için (m) kullanılır. En büyük tümör çapına göre klasifikasyon yapılır

N-Bölgesel Lenf Nodları (Santral kompartman, lateral servikal ve üst mediastinal lenf nodları)

NX Bölgesel lenf nodları değerlendirilemiyor

N0 Bölgesel lenf nod metastazı yok

N1 Bölgesel lenf nod metastazı

N1a Düzey VI metastazı (pretrakeal, paratrekeal, prelaringeal/Delphian) lenf nodları

N1b Tek taraflı, iki taraflı, karşı servikal ya da superior mediastinal lenf nodları

M-Uzak Metastaz

MX Uzak metastaz değerlendirilemiyor

M0 Uzak metastaz yok

M1 Uzak metastaz

\section{Evreleme}

TNM sistemi (Tablo 4) son revizyonda T1 tümör tanımını değiştirmiş bir cm ya da daha az olan tümör çapını iki $\mathrm{cm}$ ya da daha az olarak kabul etmiştir. Bu durumda T1 artık mikrokarsinom tanımı ile uyumlu değildir. PTC ve FTC'da kırkbeş yaşından daha az olanlarda uzak metastaz yok ise tüm $\mathrm{T}$ ve $\mathrm{N}$ gruplarında olan hastalar evre I uzak metastaz olanlar evre II olarak kabul edilir. Kırkbeş yaşından büyük olanlar ise evre I-IV arasında değişir.

\section{Tiroit neoplazilerinin morfolojik bulguları \\ Folliküler adenom}

En sık görülen tiroit neoplazmıdır. Folliküler diferansiasyon göstern kapsüllü tümördür. Kapsüler vasküler ya da herhangi bir tip invazyon göstermez. Papiller karsinomun çekirdek özellikleri bulunmaz. Farklı sonuçları olan çalışmalar olmakla birlikte folliküler adenomların çoğunda monoklonalite gösterilmiştir. Adenomlar bazı sendromlar hariç hemen her zaman tektir. Yapısal ve sitolojik özellikleri çevre parenkimden farklıdır. Çevreye bası yaparlar. Normofolliküler (basit), makrofolliküler (kolloid), mikrofolliküler (fetal), trabeküler/solid (embriyonel) olmak üzere morfolojik tipleri vardır. Ancak bunların klinik önemi yoktur. Mitoz nadir ya da yoktur. Ancak varlığı malignite anlamına gelmez. Özellikle büyük olanlarda kanama, ödem, fibrozis, kalsifikasyon, ke- mik yapımı ve kistik dejenerasyon sıktır. Papiller karsinom ya da hiperplastik nodüller ile karışabilen papiller ya da pseudopapiller yapılar bulunabilir. Bazı bilim adamları bunlara papiller adenom adını verse de papiller düzenlenim gösteren folliküler adenom daha uygun bir ifadedir. Hiperfonksiyone folliküler adenomlar sintigrafide sıcaktır. Bazen hipertiroidiye neden olur toksik ya da Plummer adenomlar adını alır. TSHR ya da GNASH1 mutasyonları bulunur. Sicak nodüllerin her zaman benign olmayabileceği akılda tutulmalıdır. $\mathrm{Bu}$ gün folliküler adenom ve folliküler karsinomu ayırabilen bir moleküler test yoktur. PAX8/PPAR $\gamma$ ve RAS her ikisinde de pozitif olabilir. PAX8/PPAR $\gamma$ ve RAS pozitif adenomlarin preinvaziv ya da invazyonu gösterilemeyen karsinomlar olabileceği tartışılmaktadır. PTEN mutasyonları genellikle bulunmaz. Germline PTEN mutasyonları Cowden sendromunda bulunur ve bu sendromda multiple follikül adenomları ve hiperplastik/adenomatöz nodüller ile karekterlidir. Carney complex tip I ve McCune-Albright sendromunda da folliküler adenomlar ve adenomatöz nodüller görülür.

Folliküler adenom ayırıcı tanısında, nodüler hiperplazinin domimnant nodülü, minimal invaziv folliküler karsinom, papiller karsinom folliküler varyant yer alır.

Standart tedavi lobektomidir.

Atipik adenom: Yapısı normalden farklı, hücresel proliferasyon belirgindir. Ancak kapsül ve damar invazyonu yoktur.

Bizar nükleus içeren adenom: Büyük hiperkromatik çekirdekler içerir ancak malignitenin diğer bulguları yoktur.

\section{Hiyalinize trabeküler adenom (HTA) ve ilişkili lez- yonlar}

Özel bir tip folliküler neoplazidir. Belirgin trabeküler yapılar ve hiyalin görünüm ile karakterlidir. Papiller karsinomun özellikleri olan psammoma cisimcikleri, çentik ve pseudoinkluzyonlar bulunur. RET/PTC rearanjmanı içerir. Ancak RAS ve BRAF bulunmaz. Papiller karsinomların metastazları HTA benzeri patern gösterebilir. HTA içerisinde papiller karsinom bulunabilir. Tüm bu nedenlerle HTA papiller karsinomun bir varyantı olabileceği öne sürülmektedir. Ancak kapsüllü ve tüm kriterleri içeren olgular benign davranır. Bu nedenle hiyalize trabeküler tümör olarak adlandırmak daha doğru olabilir.

\section{Papiller karsinom}

Papiller karsinom mikroskopik boyutta ya da çok büyük çaplı olabilir. Bir santimetreden küçük tümörlerin büyük kısmı papiller karsinomdur. Makroskopik olarak solid, sert, beyaz, invaziv kitlelerdir. Kapsüllü tümörler \% 10'dan daha azdır. Kistik değişiklik de yaklaşık \% 10 oranında görülür. Bazen papiller yapılar gözle görülür. Mikroskopik olarak tipik papiller karsinoma kolayca tanınabilen gerçek papiller yapılar içerir. Papiller yapıların fibrovasküler koru tek ya da çok sıralı küboidal hücreler ile çevrilidir. Papiller yapılara değişen miktarda follikül yapıları eşlik eder. Papiller karsinomun hücrelerinin karakteristik çekirdek özellikleri vardır. Papiller karsinom tanısı papiller yapılar olmasa dahi bu çekirdek özelliklerine dayanılarak verilmektedir.

$\mathrm{Bu}$ özellikler şunlardır:

1. Buzlu cam (şeffaf) çekirdek: Genellikle büyüktür, üst üste biner tarzda dizilenir. Membran kalındır. Çekirdekcik 
belirgin değildir ve çekirdek membranına yakındır. Bu değişiklik frozen kesitler ve sitolojide belirgin değildir. Parafin kesitlerde özellikle de yüksek konsantrasyonda formalin ile fikse dokularda belirgindir.

2. Çekirdekte yerleşen pseudoinkluzyonlar: Sitoplazmanın invajinasyonu ile oluşan iyi sınırlı asidofilik vakuollerdir. Frozen ve sitoloji preparatlarında görülebilir. $\beta$-Catenin ve bazen tip IV kollajen ile boyanır.

3. Çentikli çekirdekler: Çekirdek membranının katlantıları nedeni ile oval, iğsi hücrelerde uzun eksen boyunca görülürler. Papiller karsinomda mitoz azdır. Olguların yarısından çoğunda yaygın fibrozis vardır. Psammoma cisimcikleri olguların yarısında görülür. Diğer tiroit lezyonlarında son derece nadirdir. Bu nedenle varlıkları papiller karsinom tanısını kuvvetle düşündürür. Solid trabeküler patern ve skuamoz metaplazi olguların \% 20'sinde görülür. Bu odakların varlı̆ğ tek başına az diferansiye tümör anlamına gelmez. Bazen masum görünen TTF-1 pozitif boyanan iğsi hücreler de görülebilir. $\mathrm{Bu}$ metaplastik değişiklik mezankimal neoplazi ve anaplastik transformasyon ile karıştırılmamalıdır. Papiller tümör sıklıkla multiple odaklar şeklindedir. Bu durum lenfatik yayılım, multisentrisite ya da her ikisine birden bağlı olabilir. Damar invazyonu olguların \% 5' inde görülür. İmmünhistokimyasal olarak sitokeratin 7 pozitif, sitokeratin 20 negatiftirler. TTF-1 tiroit dokusu ve tiroit neoplazilerinin hepsinde pozitiftir. Tyroglobülin ile birlikte metastazlarda primer odağın tiroit olduğunun gösterilmesinde faydalıdır.

Papiller karsinomun immun histokimyasal profili normal follikül, folliküler hiperplazi ve benign papiller yapılardan (Graves hastalığı, nodüler hiperplazi) daha farklıdır. Benign papillalar HMBE-1, galectin-3, 34BE12 ve keratin 19 negatif, p27 pozitiftir. Ancak Papiller karsinom ve Hashimoto tiroiditinin immün profili biribirine benzemektedir.

\section{Papiller karsinom varyantları}

1. Papiller mikrokarsinom: Daha önce açıklanmıştır.

2. Kapsüle varyant: Kapsülle çevrili papiller karsinomdur. Nodal metastaz yapabilir ancak uzak metastaz ve tümöre bağlı ölüm neredeyse yoktur. Santral kistik dejenerasyon gösteren, papiller yapılar içeren nodüler hiperplaziden ayrılmalıdır. Morfolojik bulgular yanı sıra benign papiller yapıların yüksek molekül ağırlıklı sitokeratin ve S100 boyanmaması papiller yapıların yüzeyinde Alcian blue ve EMA pozitif materyal bulunmaması ayırıc tanı da yardımcı olur.

3. Folliküler varyant: Hemen tamamen folliküler yap1lardan oluşur. Papiller tip çekirdek değiş̧ikliklerin varlığ ile tanı konur. İnvaziv ise davranışı klasik papiller karsinom ile benzerdir. Kendi içinde alt tipleri vardır.

a) Solid varyant: Çocuklarda sıktır. Folliküllerden oluşan yuvarlak solid adalarla karakterlidir. Papiller tipte çekirdek özelliklerinin varlığı ile az diferansiye karsinomdan ayrılır. $\mathrm{Bu}$ ayırım davranışların farklı olması nedeni ile önemlidir.

b) Diffüz (multinodüler varyant): Bir ya da iki tiroit lobu etkilenmiştir. Bu yaygınlık nedeni ile tanı koymak zor olabilir.

c) Makrofolliküler varyant: Dilate makrofolliküllerden oluşur

d) Enkapsüle folliküler varyant: Kapsülle çevrili ancak sitolojik olarak çekirdeklerde papiller özellikler taşıyan tümörlerdir. En sık konsültasyonlar bu tümörler nedeni ile olmaktadır. Tanı için tipik çekirdek değişiklikleri yaygın ol- malıdır. İntratümöral fibrohiyalin bantlar, uzantılı dallanan folliküller, yoğun kıvamlı kolloid, abortif folliküller gibi destekleyici bulgular da bulunmalıdır. Ancak çekirdek değişiklikleri fokal olduğu zaman nasıl tanı verileceği henüz tartışmalıdır. Bu odakların galectin-3 ve HBME-1 pozitif olması ve RET/PTC rearanjmanları içermeleri benign lezyon üzerindeki erken papiller karsinomlar olduğunu düşündürmektedir. $\mathrm{Bu}$ lezyonların konservatif cerrahi ile yeterli tedavi oldukları da bilinmektedir. Bu nedenle karsinom tanısı vererek hastayı ve cerrahı gereksiz işlemlere yöneltmemek için Çernobil Patoloji Grubu aşağıdaki terminolojiyi önermiştir. Bu terminoloji çekirdek değişikliklerinin varlığına ve açıkca belirgin olup olmaması gibi subjektif yönü olan kriterlere bağlıdır.

1. Papiller karsinom folliküler varyant: Papiller karsinom çekirdek değişiklikleri açıkca belirgin ise kapsülün varlığına bakılmaksızın tanısı verilir.

2. İyi diferansiye karsinoma, NOS, (sinuflanamayan): Çekirdek değişiklikleri açıkça belirgin değil ve kapsül invazyonu vardır.

3. Malignite potansiyeli belli olmayan iyi diferansiye tümör (WDT-UMP): Çekirdek değişiklikleri açıkça belirgin değil ve kapsül invazyonu yok ya da şüphelidir. Bu tümörlerde görülen genetik değişiklikler de folliküler ve papiller karsinomlar arasında yer almaktadır.

4. Diffüz sklerozing varyant: Bu varyant bir ya da iki lobu diffüz olarak tutar. Sklerozis, çok sayıda psammoma cisimcikleri, yaygın solid alanlar ve skuamoz metaplazi alanlar1, yoğun lenfositik infiltrasyon ve yoğun lenfatik invazyonu vardır. Nodal metastaz, akciğer metastazı sıktır. Beyin metastazı olabilir. Hashimoto tiroiditi ile karışabilir.

5. Onkositik (oksifilik varyant): Daha önce açıklanmışt.

6. Tall cell karsinoma: Papiller yapılar uzunluğu eninin en az üç katı olan geniş asidofilik sitoplazmalı tek sıra hücrelerle çevrilidir. Bu özellikler tümörün en az yarısında var ise tall cell varyant olarak adlandırılmalıdır. Çok sayıda pseudoinkluzyon bulunur. Stromada yoğun lenfoid infiltrasyon olabilir. Yaşlılarda daha sıktır. Ekstratiroidal yayılım daha fazla görülür, klinik davranışın daha kötü olduğu düşünülmektedir.

7. Kolumnar hücreli karsinoma: Papiller yapılar pseudostratifiye kolumnar hücrelerle döşelidir. Sitoplazma şeffaftır ve subnükleer vakuoller içerir. Papiller karsinomun tipik çekirdek özellikleri yoktur. Bu nedenle papiller karsinomun bir varyantı olup olmadığı tartışmalıdır. Davranışı evre ile ilişkilidir.

8. Kribriform-morular varyant: Kribriform ve morular yapılarla karakterlidir. Klasik papiller karsinomdan farklı olarak mikroflamanların birikimine bağlı olarak nükleer şeffaflaşma görülür. $\beta$-catenin çekirdek ve sitoplazmayı güçlü boyarken normal tiroidte membranöz boyanmaya neden olur. Sporadik olabilir ancak bazıları kolonik adenomatöz polipozis gibi genetik olarak tanımlanan sendromların parçasıdır.

9. Artmış nodüler fasiitis benzeri stroma içeren papiller karsinoma: Belirgin olan stromal reaksiyon neoplastik epitelyal komponenti örtebilir. Bu nedenle yanlış tanılara yol açabilir.

Folliküler karsinom: Genel anlamda folliküler hücre diferansiasyonu gösteren malign tümördür. Kapsül damar ve çevre tiroit dokusuna invazyon ile karekterlidir. Mikroskobik 
olarak iyi oluşmuş folliküller, solid gelişim, çok nadiren iğsi hücrelerden bile oluşabilir. Solid kribriform ve trabeküler alanları az diferansiye karsinomdan ayırmak için mitoz ve nekroz dikkatle aranmalıdır. Folliküler adenomlarla benzer şekilde TTF-1, düşük molekül ağırlıklı sitokeratin, EMA ve laminin, tip IV kollajen gibi bazal membran komponentleri ile boyanır. Matriks metalloproteinazları MCM2 ve human telomarase reverse (hTERT) folliküler karsinomlarda adenomlardan daha fazla boyanmaktadır. Papiller karsinomda pozitif boyanan bir çok antikor ile de pozitif boyanabilmektedirler. Benzer bir genetik yol izleyerek oluştukları için, bugün folliküler adenom ve karsinomu güvenle ayırabilen bir moleküler test henüz yoktur.

Minimal invaziv folliküler karsinoma: Makroskobik olarak kapsüllü solid kesit yüzüne sahip tümörlerdir. Fetal ve embiryonel adenomlara benzer. Bazı olguların adenomun malign dönmüşümü olduğu öne sürülmektedir. Kapsül ve damar invazyonu tanı için gereklidir. Bu kriteler konusunda çok dikkatli olmak gerekir. Damar invazyonu mikroskopik olarak saptanan bir bulgudur. İnvazyon olan damar venöz boyutta olmalıdır ve kapsül ya da hemen kapsül dışında yer almalıdır. Tümör hücrelerinden oluşan küme damar duvarına tutunmuş olmalı ve lümene uzanmalıdır. Sıklıkla tümör endotel ile örtülmüş olarak gözlenir.

Kapsül invazyonu, tam kat olmalıdır. İnvazyon dar bir boyun şeklinde başlar ve kapsül içerisinde ilerledikten sonra bir mantar gibi genişler. Ancak bu genişleyen kısım sağlam kapsülle çevrili ayrı bir nodülmüş gibi kesitlere bağlı olarak görülebilir. Seri kesitlerle iki nodülün bağlantısının gösterilmesi gereklidir. Ayrıca orijinal kapsülü aşmış tümörlerde ikinci hatta üçüncü kapsül oluşumu gerçekleşebilir.İnce iğne aspirasyonuna bağlı oluşabilen kapsül hasarı invazyon ile karıştırılmamalıdır. Bu alan genellikle fissür şeklindedir kanama ve onarım değişiklikleri içerir. Ayrıca taze lezyona kesit yapılınca tümör dokusu kapsül üzerine hernie olarak invazyon ile karışan görüntülere neden olur. Bu nedenle kesitlerin en kenar kısımlarında invazyon değerlendirilmemelidir.

Kapsüllü folliküler lezyonların makroskobik örneklenmesi doğru tanı için son derece önemlidir. İyi diferansiye folliküler neoplazilerde kapsül tam olarak invaze edilmediği zaman değerlendirme farklılıkları ortaya çıkmaktadır. Çernobil Patoloji Grubu bu durum için aşağıdaki terminolojiyi önermektedir. Folliküler karsinom; Kesin kapsül invazyonu vardır ve papiller karsinom nükleer özellikleri yoktur. Maliginte potansiyeli belli olmayan folliküler tümör (FTUMP): Kapsül invazyonu şüphelidir ve papiller karsinom çekirdek değişiklikleri yoktur.

Malignite potansiyeli belli olmayan iyi diferansiye tümör (WDT-UMP): Kapsül invazyonu ve papiller karsinom çekirdek özellikleri şüphelidir (Rosai ve Tallini 2011).

Yaygın İnvaziv Folliküler Karsinom: Yüksek risklidir. Yaygın olarak damar ve/veya komşu tiroit doku invazyonu vardır. Genellikle kapsülleri yoktur. Kapsüllü olup yaygın vasküler invazyon gösterenlerin de bu gruba alınması gerektiği öne sürülmektedir. Aşağıdaki gibi bir sınıflama öneri aşamasindadir (Tablo 5).

Onkositik varyant (Hürthle hücreli karsinom)

Folliküler hücre orjinli malign neplazmlardır. Hücreleri-

\section{Tablo 5. Folliküler karsinom}

\begin{tabular}{l} 
Kapsüllü \\
Kapsüler invazyon var (vasküler invazyok yok) \\
Sınırlı vasküler invazyon $(<4)$ (kapsüler invazyon var ya da yok) \\
Yaygın vasküler invazyon $(\geq 4)$ (kapsüler invazyon var ya da yok) \\
Yaygın invaziv \\
Bu tümörlerde invazyonu yaygınlığı nedeni ile kapsül aramak gereke- \\
bilir. \\
Metastaz yaygın invaziv tipte sıktır. Damar invazyonu olan minimal in- \\
vaziv tümörlerde metastaz \% 5'den azdır. Sadece kapsül invazyonu olan- \\
larda ise \% 1'den daha azdır (Rosai ve Tallini, 2011) \\
\hline
\end{tabular}

nin $\% 75$ 'den fazlası onkositik tiptedir. Tiroit, malignitelerinin \% 3-4'ünü oluşturur. Ortalama tanı yaşı 61 dir. Kadınlarda daha sıktır. Lenf nod metastazı klasik forma göre daha fazladir.

Makroskopik olarak kesit yüzünün kızıl-kahve rengi olması tipiktir. Özellikle İIAS'den sonra olmak üzere infarkta gitme eğilimi vardır. Yaygın invaziv tümörlerin sınırları düzensizdir ve multinodüler görünüme yol açan satellit nodüller oluşturabilir. Tanı kriterleri klasik folliküler karsinom ile benzer şekildedir. Şeffaf hücreler içerebilir. Davranışının klasik formdan daha agreziv olduğu genel olarak düşünülse de bu kesinlik kazanmamıştır (DeLellis ve Williams, 2004).

\section{Şeffaf hücreli varyant}

Şeffaf hücrelerden zengindir. Taşlı yüzük tipi folliküler hücreler de görülebilir. Bu hücreler, glikojen, müsin, lipit, dilate mitokondri içerebilir. Sıklıkla onkositik tip neoplazilerde belirgin olurlar (DeLellis ve Williams, 2004).

\section{Az diferansiye karsinom (insüler karsinom)}

Klinik davranış ve morfolojik olarak iyi diferansiye ve andiferansiye tiroit karsinomlarının arasında yer alır. Bu tümörlerin bir kısmı daha önce var olan papiller ya da folliküler karsinomdan köken alırken bir kısmı de novo başlangıç gösterir. Makroskopik olarak üç santimetrenin üzerinde gribeyaz sık nekroz odakları içeren tümörlerdir. Çevreden iyi sınırla ayrılmıştır nadiren kalın kapsülü vardır. Satellit nodüller oluşturur. Tiroit dışı yayılım andiferansiye karsinomdan daha azdır. Bölgesel lenf nodlarına sıklıkla metastaz yaparlar. Karaciğer ve kemik metastazı yapmayı tercih ederler. Mikroskopik olarak insüler, trabeküler ve solid formda olabilir. Tanı için bu formların tümörün büyük kısmını oluşturması ile birlikte invaziv büyüme paterni, nekroz ve açık vasküler invazyon olması gerekir. İyi diferansiye bir tümör içerisinde küçük bir odak kötü diferansiye odak bulunması durumu tartışmalıdır. Ancak bir çalışmada bu paternin \% 10 dan fazla olmasının tiroit dışı yayılım, lenf nodu metastazı ve uzak metastaz ile birliktelik gösterdiği belirtilmiştir. Tümör hücreleri küçük üniform, yuvarlak hiperkromatik ya da vezikülo çekirdekli ve belirgin olmayan çekirdekciklidir. Mitoz sıktır. Nekroz ve fibrozis görülür. Yüzeyel olarak papiller karsinoma benzeyen çekirdekler olabilir. Şeffaf, onkositik ve rhabdoid özellikler göstern hücreler olabilir. Anaplastik özellik göstern alanlar var ise mutlak belirtilmelidir. Tiroglobülin pozitiftir. TTF-1 izole hücerlerde pozitiftir. Normal tiroit hücreleri ve iyi diferansiye tümörlerden farklı olarak E-cadherin kaybı görülür. p53 bazı hücrelerde pozitiftir. Ki-67 indeksi artmıştır. Ortalama beş yıllık yaşam yaklaşık \% 50’ dir. 


\section{Anaplastik (andiferansiye) karsinoma}

İmmunhistokimyal ya da elektron mikroskobi ile epitelyal diferansiasyonu gösterilebilen andiferansiye hücrelerden oluşan malign tümörlerdir. Yaşlılarda ve kadınlarda daha çok görülür. Mortalite hızı \% 90'ın üzerindedir. Yaklaşık yaşam süresi tanıdan sonra altı aydır. Çoğunda daha önceden var olan tiroit karsinomu bulguları vardır. Makroskobik olarak tümör büyük, beyaz-ten renklidir. Kanama nekroz alanları içerir. İnfiltratiftir. Tiroit glandı ve çevre dokuları infiltre eder. Mikroskobik olarak değişen oranlarda iğsi, hücreler, pleomorfik dev hücreler ve epiteloid hücrelerden oluşan yaygın invazyon gösteren tümörlerdir. İğsi hücreler çoğunlukta olur ise sarkomlara benzerler. Çoğu olguda mitoz sıktır. Yaygın koagulasyon nekrozu içerir. Osteoklast tipi dev hücreler ve belirgin nötrofilik infiltrat görülebilir. Sitokeratin olguların \% 80 'inde pozitiftir. Tiroglobülin hemen her zaman negatiftir. TTF-1 nadiren pozitiftir. TP53 ile kuvveti pozitiftirler.

\section{Medüller karsinom}

C hücre diferansiasyonu göstern malign tiroit neoplazmıdır. Tipik olarak glandın orta 1/3'ünde yerleşir. Makroskobik olarak sert, gri-beyaz ten rengi kapsülsüz lezyonlardır. Bir santimden daha küçük olabilirler (mikrokarsinom). Sporadik tümörler tipik olarak tek taraflı, ailevi olanlar çok sayıda ve çift taraflıdır. Mikoroskobik olarak, adalar, tabakalar, trabekül yapıları oluşturan poligonal, yuvarlak, iğsi, plazmasitoid hücrelerden oluşur. Bazen hiperkromatik, pleomorfik hatta multinükleer hücreler içerebilir. Arada değişen miktarda stroma vardır. Olguların \% 80'inde Kongo kırmızısı pozitif amiloid gösterilir. Alışılmamış morfoloji gösteren tiroit tümörlerinde medüller karsinom akla getirilmelidir. Tümör hücreleri kalsitonin ile boyanır. CEA olguların çoğunda pozitiftir. Kromogranin A ve sinaptofizin gibi nöroendokrin belirleyiciler ile boyanır. TTF-1 ve düşük molekül ağırlıklı sitokeratinler ile pozitif boyanır.

\section{Primer lenfoma}

Tüm tiroit malign tümörlerinin yaklaşı \% 5'ini oluşturur. Yaşlılarda ortalama 65 yaşta görülür. Makroskobik olarak tümör 20 santimetreye dek ulaşabilir. Tek ya da iki lobu tutar. Sert ya da yumuşak, multinodüler ya da diffüz olabilir. Kesit rengi düzgün, gri-beyaz, ten rengi, kırmızı olabilir. Nekroz kanama alanları olabilir. Çevre dokulara uzanım gösterir. Mikroskobik olarak, ekstranodal marjinal zon B-cell lenfoma (EMZ-BCL) ve diffüz large B cell lenfoma (DL-BCL) görülür. Bazen iki tip lenfoma arasında geçiş alanları olabilir. Folliküler lenfoma son derece nadir olarak tanımlanmışıtır. Hemen her zaman lenfositik tiroidit zemini vardır. EMZ$\mathrm{BCL}$, nodülerden diffüze değişim gösteren heterojen $\mathrm{B}$ hücre infiltrasyonu ve lenfoepitelyal lezyon ile karekterlidir. DLBCL ise büyük atipik lenfoid hücrelerden oluşur (DeLellis ve Williams, 2004). Özet olarak, çok farklı patolojilerin izlendiği tiroit hastalıklarında sağlıklı bir yaklaşım için klinisyen, patolog, radyolog ve nükleer tıp uzmanı başta olmak üzere çok sayıda disiplinin işbirliği gereklidir.

\section{KAYNAKLAR}

Baloch, Z.W., LiVolsi, V.A., 2004. Fine-needle aspiration of thyroid nodules: Past, present, and future. Endocr. Pract. 10, $234-241$. Boerner, S.L., Asa, L., 2010. Biopsy İnterpretation of the Thyroid. Lippincott Williams \& Wilkins. Philadelphia.

Burlingame, O.O., Kessé, K.O., Silverman, S.G., Cibas, E.S., 2011. On-site adequacy evaluations performed by cytotechnologists: Correlation With Final Interpretations of 5241 Image-Guided Fine Needle Aspiration Biopsies. Cancer Cytopathol. 120, 177-184.

DeLellis, R.A., Williams, E.D., 2004. Tumours of thyroid and parathyroid. In from World Health Organization Classification of Tumors. Pathology \& Genetics. Tumours of Endocrine Organs. R.A. DeLellis, R.V. Lloyd, P.U. Heitz, C. Eng C, eds. IARC Press, Lyon, 49-133.

Maitra, A., 2010. The Endocrine System. In from pathologic basis of disease. V. Kumar, A.K. Abbas, N. Fausto, J.C. Aster, eds. Elsevier, China, 1097-1164.

Rosai, J., Tallini, G., 2011. Thyroid gland. In from Rosai and Ackerman's Surgical Pathology. J. Rosai, ed. Elsevier, China, 487-564.

Syed, Z.A., Cibas, E.S., 2010. The Bethesda System for Reporting Thyroid Cytopatholohy. Definitions, criteria and explanatory notes. Springer. New York. 